\title{
Why not be a desertist?
}

\section{Three arguments for desert and against luck egalitarianism}

\author{
Huub Brouwer ${ }^{1}$ (D) Thomas Mulligan ${ }^{2}$ (ID
}

\begin{abstract}
Many philosophers believe that luck egalitarianism captures "desertlike" intuitions about justice. Some even think that luck egalitariansm distributes goods in accordance with desert. In this paper, we argue that this is wrong. Desertism conflicts with luck egalitarianism in three important contexts, and, in these contexts, desertism renders the proper moral judgment. First, compared to desertism, luck egalitarianism is sometimes too stingy: it fails to justly compensate people for their socially valuable contributions-when those contributions arose from "option luck". Second, luck egalitarianism is sometimes too restrictive: it fails to justly compensate people who make a social contribution when that contribution arose from "brute luck". Third, luck egalitarianism is too limited in scope: it cannot diagnose economic injustice arising independently of comparative levels of justice. The lesson of this paper is that luck egalitarians should consider supplementing their theory with desert considerations. Or, even better, consider desertism as a superior alternative to their theory.
\end{abstract}

Keywords Desert · Luck egalitarianism · Comparative fairness · Social contribution · Principles of stakes $\cdot$ Pluralism

Huub Brouwer

h.m.brouwer@tilburguniversity.edu

Thomas Mulligan

thomas.mulligan@georgetown.edu

1 Tilburg Center for Logic, Ethics, and Philosophy of Science, Tilburg University, Warandelaan 2, 5037 AB Tilburg, The Netherlands

2 Georgetown Institute for the Study of Markets and Ethics, Georgetown University, 37th and O Streets NW, Washington D.C. 20057, USA 


\section{Introduction}

If we take Aristotle at his word, the distributive justice debate was considered settled in the fourth century BC: "All people agree that what is just in distribution must be in accord with some sense of desert" (Nicomachean Ethics: 1131a).

This consensus has been lost. None of today's dominant theories of justice provides a foundational role to desert - that is, these theories do not distribute with a view to how deserving people are. ${ }^{1}$ Utilitarians reward the deserving only as an instrument for maximizing the general welfare. Egalitarians such as John Rawls (1971) would happily enrich the stupid, wicked, and indolent-if doing so redounded to the benefit of the least-advantaged class. And libertarians like Robert Nozick (1974) have no interest in establishing any pattern of distribution whatsoever: If free markets create an idle rentier class which monopolizes the product produced by diligent workers - well, so much the worse for the workers.

In 1971, John Kleinig wrote that "the notion of desert seems by and large to have been consigned to the philosophical scrap heap" (71), and in our judgment, little has changed. But some might think that desert has made a comeback of sorts, in the form of luck egalitarianism. As Shlomi Segall points out, "many luck egalitarians invoke desert, whether explicitly or implicitly" (2015: 355). These desert-invoking luck egalitarians include Richard Arneson (2007), G. A. Cohen (2011), Eric Rakowski (1991), and Larry Temkin (2017).

Our purpose in this essay is to show that not only has desert not made a comeback in the form of luck egalitarianism, the two theories are, in fact, deeply at odds. We distinguish three important contexts in which desertism conflicts with luck egalitarianism. ${ }^{2}$ Moreover, analysis suggests that desert, not luck egalitarianism, renders the correct moral verdict in these contexts.

We proceed as follows: In Sect. 2, we provide conceptual outlines of luck egalitarianism and desertism and describe the argumentative strategy we employ in what follows. Section 3 is the heart of the essay: we adduce and analyze three thought experiments which demonstrate that luck egalitarianism conflicts with desert-based justice, and we show that the latter provides the more plausible analysis. We conclude, in Sect. 4, by drawing broad lessons for the current dialectic about justice. Among these is that luck egalitarians should consider supplementing their theory with desert considerations. Or, even better, they should consider desertism as a superior alternative to their theory.

\footnotetext{
1 There are, of course, exceptions to the utter exclusion of desert from the distributive justice debate; these include, among others, the theories of Michael Walzer (1983), Wojciech Sadurski (1987), David Miller (2001), David Schmidtz (2006), Fred Feldman (2016), and Thomas Mulligan (2018). Nevertheless, we think that it is safe to say that the concept "plays an unimportant role in most contemporary theories of distributive justice" (Moriarty 2013: 537).

${ }^{2}$ We use "desertism" and "desert-based (theory of distributive) justice" interchangeably in this paper.
} 


\section{Luck egalitarianism and desertism: general principles}

Some years after Ronald Dworkin (1981a, b) first inspired luck egalitarianism, ${ }^{3}$ G.A. Cohen remarked that "Dworkin has, in effect, performed for egalitarianism the considerable service of incorporating within it the most powerful idea in the arsenal of the anti-egalitarian right: the idea of choice and responsibility" (1989: 933). Desertism also makes use of this idea, but that is perhaps the only commonality between the two theories. And even this shared concern for choice and responsibility is incorporated into the two theoretical frameworks in different ways.

Two preliminary remarks must be made. First, we cannot, within the confines of this paper, provide a complete conceptual mapping of either theory, let alone both. Doing so would be especially problematic for desertism: desert is a wonderfully rich concept, but also a maddeningly complex one. For the purposes of our argument, we need not consider all the variety in the literature on luck egalitarianism and desertism. Instead, we focus on one, mainstream, desert-based view of distributive justice, and on features of luck egalitarianism which all its major construals share. Our aim is to show that desert-based justice provides a more plausible moral analysis in three important cases than luck egalitarianism, however construed, does.

Second, we consider monistic versions of luck egalitarianism and desertism. That is, we ignore that, to decide on what is distributively just all things considered, luck egalitarians and desertists might supplement their core ideas with independent principles, such as benevolence, compassion, freedom, and/or utility ( $c f$. Temkin 2003: 63, 2017: 46; Voigt 2007: 391). What we are interested in here are the ramifications of the core ideas of both theories in the cases that we consider. ${ }^{4}$

\subsection{Luck egalitarianism}

Samuel Scheffler puts the central claim of luck egalitarianism thus: ${ }^{5}$

inequalities in the advantages that people enjoy are acceptable if they derive from the choices that people have voluntarily made, but... inequalities deriving from unchosen features of people's circumstances are unjust. Unchosen circumstances are taken to include social factors like the class and wealth of the family into which one is born. They are also deemed to include natural factors like one's native abilities and intelligence. (2003: 5)

From this central claim, the two questions that constitute much of the luck egalitarian literature arise: (1) What are the instances of bad luck ("unchosen circumstances") that give rise to unacceptable inequalities? And (2) what, exactly,

\footnotetext{
3 The term "luck egalitarianism" was coined by Anderson (1999: 289) in a critique of the theory. Dworkin (2003) resisted the label, and Arneson (2018) argues that, indeed, Dworkin should not be regarded as a luck egalitarian.

${ }^{4}$ We discuss the possibility of pluralism in Sect. 3.3.

5 See Arneson (2011) and Lippert-Rasmussen (2016) for overviews of luck egalitarianism. Prominent luck egalitarians include G. A. Cohen (1989), Kasper Lippert-Rasmussen (2001), John Roemer (1998), and Peter Vallentyne (2002).
} 
are these "advantages that people enjoy" (i.e. what is the appropriate currency of justice)?

When it comes to (1), luck egalitarians agree that not all inequalities arising from luck are unjust and therefore in need of repair. ${ }^{6}$ The problematic inequalities are those that arise from unequal brute luck. Inequalities that arise from unequal option luck need not concern us.

There are two common views on how to distinguish the two: the choice view and the control view. Proponents of the choice view hold that $X$ is brute luck for $P$ iff $P$ did not substantially and voluntarily choose $X ; X$ is option luck for $P$ iff $P$ did substantially and voluntarily choose $X$ ( $c f$. Dworkin 1981b, Cohen 2011). Proponents of the control view, on the other hand, say that $X$ is brute luck for $P$ iff $P$ does not and did not control $X ; X$ is option luck for $P$ iff $P$ does or did control $X$ (cf. Zimmerman 1993).

In some scenarios, the choice view and the control view will agree. Suppose, for example, that Alice steps up to the roulette wheel and bets a large sum of money on black. Unlucky for her, it comes up red. As a result of this loss, she is made worse off than others. Because Alice chose to gamble, and because she controlled her gambling, nearly all (see n. 6) luck egalitarians agree that her relative disadvantage is not unjust. To be sure, Alice neither chose nor controlled the roulette wheel's coming up red. But she did choose and control her participation in this "calculated gamble" (Dworkin 2000: 74) —and that, for the luck egalitarian, is the important thing.

In other scenarios, choice and control need not coincide. Suppose that Bert gets into an accident because he voluntarily chose to drive his motorcycle recklessly (and he voluntarily chose his taste for reckless riding). ${ }^{7}$ On the choice view, Bert (like Alice) may justly bear the relative burdens produced by his recklessness (e.g., his injuries). The accident is a result of bad option luck. But suppose, further, that Bert's accident was overdetermined; even if he had been careful, the accident would have occurred. On the control view, the accident would be a case of bad brute luck-because Bert had no control over it-and therefore is amenable to compensation by the state.

The second major question, (2), confronting luck egalitarians (and indeed, all theorists of justice) is specifying the currency of justice. Dworkin regards resources as the currency, where these are akin to and include the standard notion of social goods (Dworkin's definition is more expansive than the standard notion-see his 1995). Others, like Arneson (1989, 2000, 2016), disagree, holding that a person suffers from unjust disadvantage when his (access to) welfare is lower than it would have been, had the bad brute luck circumstances not obtained. ${ }^{8}$ And Cohen

\footnotetext{
6 The exception is what Segall (2010: 46) deems "all-luck egalitarianism", which maintains that all luckderived inequalities are unjust. We suspect that all-luck egalitarianism collapses into a form of outcome egalitarianism.

7 This example is adapted from Fleurbaey (1995: 40-41).

${ }^{8}$ Note that Arneson (1989) initially defended subjective welfare, but has since abandoned this view. He now defends an objective welfare account (see his 2016).
} 
(1989, 2011) thinks that luck egalitarians ought to concern themselves with inequalities in both.

Taking these distinctions into account, luck egalitarianism can be partitioned into four theoretical approaches: choice-resources, choice-welfare, control-resources, and control-welfare. We shall show in Sect. 3 that our argument is sound no matter which the luck egalitarian elects.

\subsection{Desertism}

Serena Olsaretti aptly characterizes the literature on desertism as a "fairly eclectic collection of contributions by desert theorists whose views differ widely" (2004: 6). But here, too, there is a unifying claim: It is unjust when people do not get the things that they deserve. Defenders of desert-based distributive justice agree also on three basic features thought central to the concept of desert. ${ }^{9}$

First, desert claims minimally consist of (1) a subject, that (2) deserves an object or mode of treatment, given (3) a certain base. For instance, Mo (the desert subject) deserves to win the gold medal (the desert object) because he was the fastest runner (the desert basis). For desert to function as a principle of distribution, it is insufficient to say that Mo deserves the medal; there must be a base or bases for awarding it to him (although this is often left implicit). It is also insufficient to say that Mo was the fastest runner; we must also have an object or mode of treatment in mind that he is morally entitled to.

Desert claims are, second, subject to an "aboutness principle": the bases must bear a proper relationship to the desert subject. ${ }^{10}$ This principle rules out claims like: "Mo deserves the medal because his parents will cry if he does not get it". While the distress of Mo's parents could in theory entitle Mo, morally, to the trophy (on a utilitarian account, for example), their distress could not make Mo deserving.

We shall not give a specification of the aboutness principle here, both because we do not wish to make any controversial assumptions and, more importantly, because the cases we adduce in Sect. 3 are valid on many specifications. We only note that it is frequently cashed out in terms of responsibility. ${ }^{11}$ On this view, it's not enough that the desert basis be about the desert subject; she must also be responsible for that basis. $^{12}$

Just as there is some necessary relation between the desert subject and the desert basis (whether it's responsibility or something else), there is a necessary relation between the desert object and the desert basis. This is generally put in terms of "fit":

\footnotetext{
9 See Feldman and Skow (2015) and McLeod (2013) for contemporary overviews of desert. Pojman and McLeod (1999) provide excerpts from important historical and contemporary texts on desert. The seminal conceptual work on desert was done by Feinberg (1963), Kleinig (1971), and Sher (1987).

10 See Feinberg (1963: 72-73), Feldman (2016: 42), Olsaretti (2003: 4), and Sadurski (1987: 117).

11 A well-known exception is Feldman $(1995,1996,2016)$ who holds that we can be deserving without being responsible for our performance on a desert base-for instance, we can be deserving on the basis of how needy we are. For a careful discussion of Feldman's arguments, see Smilansky (1996a, b).

12 There are many ways in which the responsibility requirement can be fleshed out. For helpful discussion, see Pojman and McLeod (1999: 114-48) and Sie and Pereboom (2016).
} 
Mo's athletic performance may make him deserving of a medal, but not of a multibillion-dollar fortune.

For the purpose of this paper-comparing luck egalitarianism and desertism-we shall assume that people deserve the currency of justice on the basis of their social contributions. We do this for two main reasons. First, it is a central position among the (admittedly small) community of desert theorists. So there will be nothing idiosyncratic in the desert-based approach that we commend here. David Miller (2001), for example, in his pluralist account of distributive justice, says that people deserve on the basis of their contributions, where "contribution" is measured by aggregating the reservation prices of consumers. And one of us (Mulligan 2018) has advanced a monistic theory of desert-based justice in which people deserve income on the basis of their contributions, as measured by the amount of additional output they provide (and where Shapley value is used to disentangle joint production). ${ }^{13}$

Second, the contribution account of desert-based justice is conservative-not in the political sense, but because it is compatible with the neoclassical conception of the market, and because its implementation would not produce an unrecognizable change to economic practice ( $c f$. Mulligan 2018, part III).

\section{Three thought experiments, three differences}

Talk about desert is ubiquitous in the luck egalitarian literature. Indeed, some philosophers reckon that the concepts themselves are intimately connected; Nicholas Barry, for example, says that luck egalitarianism is "both an egalitarian and a desert-based theory" (2006: 102).

But the demands of luck egalitarianism and desertism come apart in a number of important and frequently occuring instances. We illustrate this phenomenon by way of three thought experiments. We shall see that at times the desertist regards the luck egalitarian as too stingy (Sect. 3.1), and at other times too restrictive (Sect. 3.2). And the two theories differ in scope: Luck egalitarianism is concerned only with the justness of differences in the level that people have of a currency of justice, whereas desertism is also concerned with the justness of the level itself (Sect. 3.3).

\subsection{Too stingy: the burning house ${ }^{14}$}

Tracy lives in a neighborhood with many timber-framed houses. One morning, she wakes up to the cries of her neighbor, Shirley. Shirley's house is on fire and she cannot escape. Tracy calls the fire brigade and waits, but when

\footnotetext{
13 There is, indeed, a small but lively discussion among desert theorists about how to measure social contribution. In addition to Miller (2001) and Mulligan (2018), see Dekker (2008, 2010), Hsieh (2000), and Sheffrin (2013).

14 The Burning House is similar in structure to examples considered by Dekker (2009), Eyal (2007), Moriarty (2018), Olsaretti (2009), Stemplowska (2009), and Temkin (2003). We raise new objections to the solutions that they propose for accomodating rewards for costly, praiseworthy actions within luck egalitarian theory.
} 
Shirley's cries stop, Tracy decides to try to save Shirley herself. Tracy gets a ladder, climbs into Shirley's house through a window, finds Shirley lying unconscious on the floor, and carries her out of the house. Shirley survives. Unfortunately, the rescue leaves Tracy injured from burns and smoke inhalation. Tracy requires expensive treatment at the hospital, which means that her resource holdings decrease. Her welfare has also dropped considerably as a result of her injuries.

Could Tracy, compatibly with justice, receive compensation for the drop in her resource holdings (the resources view) and welfare (the welfare view)?

The luck egalitarian answer is clear: No (cf. Eyal 2007: 4; Moriarty 2018). Why? Because Tracy chose to save Shirley (the choice view) and because she had control over her decision to save Shirley (the control view).

We find this morally implausible. Tracy ought to receive compensation for her actions, which should include (the resources required for) medical care for her injuries. Luck egalitarianism has no conceptual mechanism for providing such care. Luck egalitarianism is too stingy when it comes to parceling out aid to people like Tracy - sufferers of bad option luck who voluntarily made socially valuable choices at high cost to themselves. Shirley will live (and may work), social ties are tightened, and the community has been strengthened-all because of Tracy's heroism.

Objection 1: Shared duties (Stemplowska 2009: 243-45) In response to scenarios like this, some luck egalitarians argue that critics interpret their theory too narrowly, ignoring the requirement that people face equal options before justice requires that they bear a disadvantage. People's options are equal only if "they make it possible to enjoy (face) the same combination of benefits (burdens) at the same cost, except where the differences are controlled by the agent whose opportunities are being assessed" (Stemplowska 2009: 244).

In the Burning House case, the equal options constraint could allow luck egalitarians to claim that all members of society share a duty to save others in lifethreatening circumstances, and that people should receive compensation if they bear a disproportionate share of this duty. If that were true, then perhaps Tracy should receive compensation, since she bears more of the physical and psychological costs of the duty to save than others do.

Reply to objection 1: Supererogation Although stressing that luck egalitarianism requires equality of options may sometimes help the luck egalitarian evade harshness objections, the strategy is not successful here. Saving people at a significant risk to one's health, which is what Tracy does, goes beyond the call of shared duties-especially if one has already tried to carry out one's duty without incurring a serious risk of getting in harm's way. Observe that we would not blame Tracy if she had chosen not to try to save Shirley by entering the burning house.

Our worry about luck egalitarianism, then, can be rephrased to say that luck egalitarianism cannot hold that justice requires reimbursing people for making costly, praiseworthy, voluntary choices that are supererogatory. This is a problem for luck egalitarianism, because there are many cases in which we value it when people go beyond the call of duty, and in which we think they ought to be 
compensated for this: Someone voluntarily resigning from his job to care for a sick family member; someone risking her life in defense of her country; someone donating an organ, putting her own life in danger, to help another who is in urgent need. And, we stress, all of these actions make a bona fide social contribution.

Objection 2: Innocent choice (Eyal 2007) Nir Eyal has responded to scenarios such as the Burning House by arguing that luck egalitarianism needs to be replaced with "modified luck egalitarianism", defined as follows:

That someone incurs a disadvantage without having chosen culpably to risk incurring it is, in a central respect, unjust. If, however, that disadvantage results from that person's own culpable choice to take that risk, then (barring prioritarian considerations) that disadvantage can remain perfectly just. "Culpable" choice is understood as a free and at least somewhat morally wrong choice. (2007: 6)

In other words, on Eyal's modified version of luck egalitarianism, it is not voluntary choice that determines the cut between brute luck and option luck, but culpable choice.

Reply 1 to objection 2: Neutrality Many luck egalitarians, and many liberal egalitarians generally, will be loath to endorse Eyal's theory on the grounds that it conflicts with the liberal commitment to neutrality in justification-the idea that (on one common definition) state action should not be justified by appeals to particular conceptions of the good. ${ }^{15}$ The extent to which it violates neutrality in justification will depend on the definition of "somewhat morally wrong"-something Eyal does not make precise. But it is very unclear how this moral wrongness could possibly be hashed out in value-free terms.

Reply 2 to objection 2: Contribution matters More importantly, however: Luck egalitarians willing to abandon neutrality are better served by simply endorsing one of the desert views discussed in Sect. 2.2-which, to be clear, also violate the commitment to neutrality in justification. This we shall justify at some length in Sects. 3.2 and 3.3; here we point out that Eyal anticipates this reply and offers two rejoinders to it. But neither is convincing.

First, Eyal asks the reader to

[i]magine a society in which a principle of desert is being strictly followed. The results of all gambles are effectively obliterated. Optional gamblers are granted precisely what they deserve. Gamblers' lots are of course tied to the fact that they gamble, which affects their deserts. However, their lots are not tied to the arbitrary outcomes of their gambles, namely, to their option luck. Plainly, such a society differs from a (standard or modified) luck-egalitarian one. Strict adherence to a desert principle obliterates all luck, regardless of whether it is brute luck or option luck, luck following innocent choice or culpable choice. (2007: 8)

\footnotetext{
15 As Gaus (2005) points out, there is a wealth of different definitions of neutrality in justification. Eyal's modified luck egalitarianism would conflict with neutrality under many of these. Quong (2011: 12-44) discusses the importance of neutrality to liberal egalitarians.
} 
This is incorrect. "Strict adherence to a desert principle" does not obliterate all luck. The reason for this is that the aboutness principle (Sect. 2.2) must be kept in mind. To deserve in the distributive sphere it is necessary that a contribution be made, but it is not sufficient. The contribution must also bear a proper relationship to the desert subject; to wit, it must satisfy the aboutness principle. For example, if aboutness is construed as a principle of responsibility (cf. Miller 2001: 147-55; Olsaretti 2006: 438-44), then, on certain conceptualizations of responsibility, gamblers' lots are tied to the arbitrary outcomes of their gambles-pace Eyal. One such a conceptualization could be that if Smith voluntarily chose to risk his life's savings at the roulette wheel, then he, and he alone, is responsible for his subsequent financial circumstances, whatever they be.

The second objection Eyal levels against desertism is that it might not offer a large enough reward to compensate for bad option luck:

[Desert] permits a person who risks having his own house burnt in order to save a neighbor's baby to receive a prize for his praiseworthy act. But that prize need not be nearly as substantial as the loss of his home. A person's praiseworthy decision to focus on the neighbor's baby need not be praiseworthy enough to call for a substantial enough award: one may save the baby when the risk to one's own house is still low. In this instance, the decision will be only somewhat praiseworthy, justifying only a small desertbased prize. (2007: 9)

There are two problems with this objection.

First, Eyal implicitly assumes a virtue-based theory of desert (with the operative principle being something like, "wealth should vary in proportion to moral virtue"). This is not the last time we shall encounter this strawmanning tactic; we reiterate (Sect. 2.2): The consensus among desertists is that one's contributions-not one's virtue-ground one's economic deserts.

Think of it this way: even though most people believe that claims about who deserves the gold medal make perfect sense, few think that it's the most virtuous runner who deserves the medal. Rather, most people think that athletic performance-not virtue-is the right basis. Similarly, it's the most beautiful contestant who deserves the tiara, not the most morally upright. And so on. So there is no need to insist, as opponents of desert often do, that virtue must ground one's distributive deserts. Indeed, the theories in both Miller (2001) and Mulligan (2018) could require that we reward the contributions of the vicious.

There is a second problem with this objection. The luck egalitarian idea which Eyal applauds is that our hero ought to be "made whole" after saving the babythat is, be fully compensated for the loss of her house. But this is implausible in some cases. Suppose, for example, that our hero's home is lavish and expensive (but not unjustly owned; i.e., she purchased it with resources gained through good option luck). Our hero rushes out of it in the middle of the night and saves the child-but then watches as her estate burns to the ground.

We all agree that she ought to receive many things for her heroic act—profound thanks, society's admiration, and, to be sure, some compensation. But does justice really require that she be compensated millions upon millions of dollars for her loss? 
(Keep in mind, by design of Eyal's example, she freely chose not to insure against this loss. For some luck egalitarian theories, that would obviate the need for compensation-but not for his modified luck egalitarianism.) Perhaps intuitions differ, but we do not think justice requires that our hero be made whole-and desert-based justice, which responds to the contribution, not the loss, agrees.

Objection 3: Incorporating desert (Arneson 2011; Dekker 2009) Finally, some luck egalitarians have responded to scenarios such as the Burning House by adjusting their theories to incorporate considerations of desert. They argue that desert can provide luck egalitarianism with a principle of stakes, which identifies the consequences of people's voluntary choices. ${ }^{16}$ If desert is used as principle of stakes, then people should only bear a subset of all the consequences of their voluntary actions: namely, the consequences that are deserved. On this, desertadjusted, variant of luck egalitarianism, Tracy ought to be compensated for her medical expenses, since she incurred them while making a sizeable social contribution.

Reply 1 to objection 3: Neutrality (encore) An obvious worry about using desert as a principle of stakes is that this would be subject to a similar concern as Eyal's modified luck egalitarianism. Desert-based theories, such as the one we adopt in this paper, conflict with the liberal commitment to neutrality in justification. By holding that certain acts constitute a social contribution which deserves to be rewarded, this view privileges conceptions of the good that agree with the definition of social contribution.

As we noted already, not all luck egalitarians are committed to neutrality in justification. Those who are, however, will be hesitant to incorporate desert for this reason.

Reply 2 to objection 3: Restrictiveness Relatedly, adopting desert as a principle of stakes would unduly narrow the category of social contributions that should be rewarded. People can, compatibly with justice, deserve rewards for their social contributions even when these contributions are due to brute luck circumstances. To see this, consider the case of the Personal Computer Revolution.

\subsection{Too restrictive: the personal computer revolution}

Bill Gates had a vision: to revolutionize the computer industry and put a personal computer in every home. Through his native intelligence, the good fortune of being born to wealthy parents, and his work ethic, he succeeded. Today, he is a wealthy and happy man.

Is it just that Gates is wealthier and happier than others?

The luck egalitarian thinks not. Gates did not choose his intelligence, diligence, or his other natural traits. The same can be said for his social circumstances. Nor did he control these. Consequently, Gates's wealth, so it is claimed, should be taken from him and redistributed to those who had worse brute luck.

$\overline{16}$ Olsaretti (2009) offers an extensive discussion of formulating principles of stakes. 
For the desertist, that result is wrong-or at least too quick. After all, Gates made a bona fide social contribution. Moreover, quite independent of justice (see n. 19) we, as a society, should like to incentivize the acquisition of skills and the achievements of people like Gates.

The precise size of Gates's just reward will depend on how the aboutness principle is specified. Some desert theorists hold what Olsaretti (2006: 438-41) calls the "conventional view" of the principle, on which the only luck that Bill's income should be corrected for is "performance luck"-that is, unforeseeable circumstances that affect Bill's success (such as the unexpected death of a major competitor). On this view, neither Bill's "luck in the natural lottery" (e.g. his intelligence) nor his luck in the social lottery (his rich parents) undercuts his desert (cf. Miller 2001: 147-55, Schmidtz 2002).

Other desertists defend more stringent versions of the aboutness principle, and say that desert is not only undercut by performance luck but also by social luck, and by some forms of natural luck (cf. Olsaretti 2006: 444-48). On these views, Bill could keep less of his wealth than on the conventional view-but more than would be compatible with luck egalitarianism.

In any case, the important point is that situations like these-in which we wish to reward contribution no matter whether it was chosen or not-are ubiquitous. As just one more example, it seems that stay-at-home parents make a bona fide social contribution by caring for the labor force of the next generation and improving its human capital. If that is so, then these stay-at-home parents deserve a state-provided income.

Suppose, however, that Ann has a child because she chose to get pregnant; Nancy has a child because of unchosen circumstances (e.g., the prophylactic failed). The luck egalitarian suggests that Nancy deserves compensation for her social contribution but Ann does not. The desertist says that both deserve compensation-a result that strikes us as more plausible.

When the luck egalitarian flat-out denies that social contributions arising from brute luck should be rewarded, it places her in a desert dilemma: Either the luck egalitarian goes on to deny that the effects of option luck can be undeserved, which leads to the objection that the theory is unduly harsh on people who voluntarily make social contributions at high costs to themselves (Sect. 2.1). Or, the luck egalitarian holds that social contributions arising from option luck should be rewarded but social contributions arising from brute luck should not be-and that is ad hoc.

Now, the luck egalitarian may at this point lodge an objection; namely, that our critique ignores the fact that many luck egalitarians are pluralists who hold that to decide whether a distribution is just, luck egalitarian theory must be supplemented with other moral principles-such as beneficence, compassion, a communitarian principle, and/or freedom. And a pluralist theory which included luck egalitarianism might be able to evade criticisms about restrictiveness.

We acknowledge that pluralism may help the luck egalitarian in this way. But it comes at a high cost. We discuss the cost of pluralism in conjunction with a third difference between luck egalitarianism and desertism, which we turn now to consider. This difference, which has received insufficient attention in the literature, 
provides another reason to prefer desertism to luck egalitarianism. Here, the problem is that luck egalitarianism is only concerned with the justness of differences in the level of a currency of justice between people, not with the justness of the level itself. Desert is sensitive to both.

\subsection{Deserved levels: a Malthusian state ${ }^{17}$}

In the agrarian state of Ludville, the government is wholly committed to justice in accordance with luck egalitarian principles. Every year, the government redistributes in order to neutralize any and all resource (or welfare) differences that arose out of unequal brute luck circumstances. Let us suppose that Ludville's government has perfect information about which inequalities were due to brute luck (and thus in need of repair) and which were not (i.e., which were due to option luck).

Ludville's government has another odd feature: It burns up-literally-a huge share of the social product. As a result, almost all of Ludville's citizens live, unequally, at a near-starvation level. Every couple of years, when the harvest is bad, there is famine, and there is death.

Is the distribution in Ludville just?

According to the luck egalitarian it is, as there are no inequalities in resources or welfare that arose from brute luck. While luck egalitarians might viscerally regard Ludville as an unjust place, that finding is not yielded by luck egalitarian principles.

G. A. Cohen says that "there is injustice in distribution when inequality of goods reflects not such things as differences in the arduousness of different people's labors, or people's different preferences and choices with respect to income and leisure, but myriad forms of lucky and unlucky circumstance" (2000: 130). In Ludville, the inequalities that do exist result, ex hypothesi, from legitimate choices to, for example, work harder and longer. A conclusion of injustice can only be drawn if the luck egalitarian principles are supplemented by other considerations, ${ }^{18}$ such as a concern for the needs of Ludville's citizens.

Therefore, to show the conceptual distinctness of luck egalitarianism and desertism, it suffices to show that the latter can straightforwardly capture the fullness of distributive injustice in Ludville. The desertist points out that everyone who makes a social contribution non-comparatively deserves to get a certain amount of social product in return ( $c f$. Hurka 2003; Kagan 2012; Miller 2003). That is, a person should get the amount of social product he or she deserves, and that is in part determined by the size of her inputs. One does not simply assume, as luck egalitarianism implicitly does, that the size of the distributive pie is irrelevant.

\footnotetext{
17 This example is adapted from Feldman (2016: 138-39). As Brouwer and Van der Deijl (2017) and Dekker (2016) argue, the notion of desert that Feldman assumes is not distinctive. Hence, we are not convinced that Feldman succeeds in showing that desertism can avoid this Malthusian objection. We argue here that contribution-based desertism successfully avoids it.

${ }^{18}$ Tan (2008) makes some suggestions along these lines.
} 
Objection: Pluralism The luck egalitarian here again has an objection based in pluralism. It goes like this: Of course there is something wrong with the distribution in Ludville. But that wrongness is of a kind that luck egalitarianism is not intended to diagnose. If luck egalitarianism is really just a theory of comparative fairness, for example, then perhaps our criticism of luck egalitarianism is misplaced. This view has been best advanced by Temkin (1993, 2011, 2017). As he puts it,

[o]n close examination, the intimate connection between equality and fairness illuminates the ultimate role that luck plays in the egalitarian's thinking, as well as the relevance and limitations of the well-known "through no fault or choice of their own" clause. Among equally deserving people, it is bad, because unfair, for some to be worse off than others through no fault or choice of their own. But among unequally deserving people it isn't bad, because not unfair, for someone less deserving to be worse off than someone more deserving, even if the former is worse off through no fault or choice of his own (2017: 45-46)

One is immediately struck by all this talk about desert by a luck egalitarian. And, indeed, the most straightforward reply to Temkin is that he is really a desertist and not a luck egalitarian. But we'll get to that in a moment.

Reply: The disadvantages of pluralism We do not dispute that pluralism is likely necessary at some level. After all, it may be that the concept of justice itself does not encompass everything that we think morally relevant to economic life. ${ }^{19}$ If that is so, then no theory of justice can fully answer every question about how we ought, morally, to arrange our economy.

What is important for our purposes in this paper is that, in the scenarios described, desert monistically renders the intuitively correct moral verdict. Luck egalitarianism, in constrast, constantly has to be supplemented: by principles of beneficence, or efficiency, or non-comparative fairness, etc.

Occam's Razor tells us that we should not multiply entities without need, but luck egalitarians like Temkin would have us do precisely that in order to account for the intuitions that luck egalitarianism misses. But when it comes to justice, just as when it comes to the natural world, we should aspire to a theory that "explains various large and independent classes of facts" (Darwin 1868: 8); that "bring[s] order to phenomena that in its absence would be individually isolated" (Kuhn 1977: 322). Desertism has greater explanatory power than luck egalitarianism.

More seriously, as we have seen, there are some cases (the Burning House, the Personal Computer Revolution) in which luck egalitarianism can render a clear and monistic verdict - but it appears to be the wrong one. This casts doubt not on the generality of luck egalitarianism, but on its truth. As these cases suggest, the fact that someone made a valuable contribution is of greater fundamental importance,

\footnotetext{
19 Konow (2001) finds that human beings share three "distributional goals": "just deserts, need, and incentives for productivity [i.e. efficiency]" (p. 139). In other words, (1) giving people what they deserve is what we mean by "justice", (2) need and efficiency are also morally important (though less important than justice/desert), and (3) need and efficiency may conflict with justice (and each other) in some cases.
} 
from the point of view of distributive justice, than whether that person voluntarily chose her actions (or was in control of them).

Finally, there is a pragmatic worry. Suppose that Temkin is right and the proper domain of application of luck egalitarianism is "comparative fairness". Further suppose that we want to pursue justice in our world by applying luck egalitarian theory. We face hard questions: How is comparative fairness related to noncomparative fairness? Are fairness and justice coextensive, or could some distribution be fair but unjust? In such a case, which takes priority? What role is there for rights? For communal values? When must communal values be ceded to rights, rights ceded to fairness, and fairness ceded to communal values?

While luck egalitarians are certainly not alone in dodging conceptual complexities, if they cannot even tell us what fairness demands, let alone distributive justice, then it is hard to see what value the theory has for the real-world pursuit of justice.

As an aside, another pragmatic concern, which again favors desertism over luck egalitarianism, is efficiency ( $c f$. n. 19). A redistributive system that provides resources or welfare-enhancements in proportion to laziness or incompetence is driven toward zero output. Everyone suffers. Yet a luck egalitarian system might well do this-if those traits are had as a matter of luck. In contrast, the plausible desert bases in the economic realm, including contribution, are all connected to a person's productivity - the amount of output she can produce per unit time. Put differently, by giving people what they deserve we naturally promote the right economic incentives. As Paul Krugman reminds us, "productivity isn't everything, but in the long run it is almost everything. A country's ability to improve its standard of living over time depends almost entirely on its ability to raise its output per worker." (1994: 11).

Some luck egalitarians have felt the theoretical allure of desert, as evidenced by the extent to which talk about desert suffuses the luck egalitarian literature. These luck egalitarians resist the notion that the ubiquity of desert should incline them to desert-based justice. We believe that this resistance will ultimately fail. To illustrate, let's consider two examples Temkin gives, which are supposed to prove that he is, pace all his desert talk, not actually a desertist deep down. Neither persuades.

Example 1: The afterlife (Temkin 2017: 57-58) Amy and Brett begin their adult lives with equal talents and equal resources. Brett freely makes some supererogatory sacrifices on behalf of worthy goals, and these leave him worse-off than Amy. According to Temkin, Brett may deserve more than Amy in the afterlife, but it is at the same time fair that he has fewer resources/less happiness than Amy does in the physical world. So, Temkin's story goes, a principle of responsibility-sensitive equality is what undergirds claims about just distribution-not a principle of desert.

Reply to example 1: Justice in the afterlife Either there is an afterlife or there is not. Suppose that there is an afterlife. Then the desertist agrees: There's nothing wrong with Brett's temporarily poor lot in life. Why? Because it'll all be made right in the end, once Brett passes through the pearly gates. The scenario is akin to the Burning House: There's nothing morally wrong with Tracy suffering temporary injury from her heroism. What is important is that justice be done: that society compensate Tracy for her heroism; that God do the same for Brett. 
Suppose that there isn't an afterlife. Now, wouldn't we think it bad-unjust and unfair-that Brett is poorly off because of his noble actions? Wouldn't we want to say something like, "how unfair it is, that Brett will never receive what he deserves for the sacrifices he has made on behalf of others"? We want to say such a thing, and we would like to know how Temkin would respond to a case like this, especially since elsewhere (2017: 46) he suggests that some supererogatory actions need to be rewarded. Any answer other than "not unjust" makes him a desertist.

Example 2: Having children (Temkin 2017: 58) Bo and Qing begin their adult lives with equal talents and equal resources. Both are equally morally deserving. Qing has children and Bo does not, leaving Qing with fewer resources to spend on himself. Temkin says this is fair, but then suggests that desert requires that they be equal in this respect (since they are equally deserving): "Having children and sacrificing on their behalf wouldn't make Qing a less virtuous or less morally deserving person than Bo... [I]t is perfectly plausible to believe that such free and responsible choices don't make Qing less deserving of a good life than Bo" (58).

Reply: Mutually beneficial exchanges Temkin strawmans desert-based justice here. Even if there were a viable theory of virtue-based desert that had the implication Temkin suggests, many theories do not have this implication. The mainstream desertist theory on which we rely certainly does not. To see this, consider Smith, who deserves $D$ dollars on the basis of his social contribution. He decides to spend $d$ dollars of it on a book. Now there's supposed to be injustice, because Smith deserves $D$ dollars, but in fact he only has $D-d$, plus a book?

No desert-based theory of justice that subscribed to such a view could possibly serve as an operative theory of distributive justice, since it rules out the possibility of mutually beneficial trades. An economy in which (1) resources are distributed on the basis of social contribution and (2) deserved resources may be exchanged between citizens for goods and services as they see fit is a perfectly coherent one.

So Qing's choice about whether to raise children or not is irrelevant for determining whether her income is deserved. The distributor doesn't look at Qing's personal life, but at his economic activity: Did Qing make bona fide contributions to the economy (in which case his income is deserved), or did he steal it, extract rents from his firm, or the like (in which case it is not)?

\section{Conclusion}

Our world is one in which nearly all people consider themselves "friends of desert" (Kagan 2012: 3). There is, thus, a gap between the centrality of desert-like intuitions in people's reasoning about justice and the presence of desert in political theory. ${ }^{20}$ Although some philosophers may think that this gap has already been bridged by luck egalitarianism, we have shown in this paper that that is incorrect. All of the major construals of luck egalitarianism conflict with one dominant version of desertism. And at these three points of conflict, desertism has the better side of

$\overline{20}$ As noted in Miller (2001), Mulligan (2018), and Scheffler (1992). 
things. Desertism is more intuitively appealing, more flexible, and does not produce the unsavory consequences of luck egalitarianism.

Acknowledgements We wish to thank audiences at the Erasmus Institute for Philosophy and Economics (EIPE) PhD seminar (February 2017), the EIPE 20th anniversary conference (March 2017), the ninth European Conference in Analytic Philosophy (August 2017), the fifteenth Pavia Graduate Conference in Political Philosophy (September 2017), the fifth annual conference of the Dutch Research School for Philosophy (November 2017), and the second PPE society meeting (March 2018); an anonymous referee for Philosophical Studies; and Alfred Archer, Rutger Claassen, Willem van der Deijl, Teun Dekker, Bart Engelen, Zoé Evrard, Andrea Gammon, Jasper van den Herik, Tim Klaassen, Serena Olsaretti, Maureen Sie, and Jojanneke Vanderveen for helpful comments on draft versions of this paper.

Open Access This article is distributed under the terms of the Creative Commons Attribution 4.0 International License (http://creativecommons.org/licenses/by/4.0/), which permits unrestricted use, distribution, and reproduction in any medium, provided you give appropriate credit to the original author(s) and the source, provide a link to the Creative Commons license, and indicate if changes were made.

\section{References}

Anderson, E. S. (1999). What is the point of equality? Ethics, 109(2), 287-337.

Arneson, R. J. (1989). Equality and equal opportunity for welfare. Philosophical Studies, 56(1), 77-93.

Arneson, R. J. (2000). Welfare should be the currency of justice. Canadian Journal of Philosophy, 30(4), 497-524.

Arneson, R. J. (2007). Desert and equality. In N. Holtug \& K. Lippert-Rasmussen (Eds.), Egalitarianism: New essays on the nature and value of equality (pp. 262-293). Oxford: Clarendon Press.

Arneson, R. J. (2011). Luck egalitarianism-a primer. In C. Knight \& Z. Stemplowska (Eds.), Responsibility and distributive justice (pp. 24-50). Oxford: Oxford University Press.

Arneson, R. J. (2016). Does fairness require a multidimensional approach? In M. D. Adler \& M. Fleurbaey (Eds.), The oxford handbook of wellbeing and public policy (pp. 588-614). Oxford: Oxford University Press.

Arneson, R. J. (2018). Dworkin and luck egalitarianism: A comparison. In S. Olsaretti (Ed.), The oxford handbook of distributive justice (pp. 41-64). Oxford: Oxford University Press.

Barry, N. (2006). Defending luck egalitarianism. Journal of Applied Philosophy, 23(1), 89-107.

Brouwer, H. M., \& Van der Deijl, W. J. A. (2017). Review of distributive justice: Getting what we deserve from our country, F. Feldman. Economics \& Philosophy, 33(1), 146-153.

Cohen, G. A. (1989). On the currency of egalitarian justice. Ethics, 99(4), 906-944.

Cohen, G. A. (2000). If you're an egalitarian, how come you're so rich? Cambridge: Harvard University Press.

Cohen, G. A. (2011). On the currency of egalitarian justice: And other essays in political philosophy. Princeton: Princeton University Press.

Darwin, C. (1868). The variation of animals and plants under domestication (Vol. 1). London: John Murray.

Dekker, T. (2008). Desert and distributive efficiency. Ethics and Economics, 5(2), 1-23.

Dekker, T. (2009). Choices, consequences and desert. Inquiry, 52(2), 109-126.

Dekker, T. (2010). Desert, democracy, and consumer surplus. Politics, Philosophy \& Economics, 9(3), $315-338$.

Dekker, T. (2016). Review of distributive justice: Getting what we deserve from our country, F. Feldman. Erasmus Journal for Philosophy and Economics, 9(2), 208-212.

Dworkin, R. (1981a). What is equality? Part 1: Equality of welfare. Philosophy \& Public Affairs, 10(3), $185-246$.

Dworkin, R. (1981b). What is equality? Part 2: Equality of resources. Philosophy \& Public Affairs, 10(4), 283-345. 
Dworkin, R. (1995). Foundations of liberal equality. In S. Darwall (Ed.), Equal freedom: Selected tanner lectures on human values (pp. 190-306). Ann Arbor: University of Michigan Press.

Dworkin, R. (2000). Sovereign virtue. Cambridge: Harvard University Press.

Dworkin, R. (2003). Equality, luck and hierarchy. Philosophy \& Public Affairs, 31(2), 190-198.

Eyal, N. (2007). Egalitarian justice and innocent choice. Journal of Ethics \& Social Philosophy, 2(1), $1-18$.

Feinberg, J. (1963). Justice and personal desert. In C. J. Friedrich \& J. W. Chapman (Eds.), NOMOS VI: Justice (pp. 69-97). New York: Atherton.

Feldman, F. (1995). Desert: Reconsideration of some received wisdom. Mind, 104(413), 63-77.

Feldman, F. (1996). Responsibility as a condition for desert. Mind, 105(417), 165-168.

Feldman, F. (2016). Distributive justice: Getting what we deserve from our country. New York: Oxford University Press.

Feldman, F. \& Skow, B. (2015). Desert. In E. N. Zalta (Ed.), Stanford encyclopedia of philosophy, Winter 2015 edition. http://plato.stanford.edu/archives/win2015/entries/desert/. Accessed 22 May 2018.

Fleurbaey, M. (1995). Equal opportunity or equal social outcome. Economics and Philosophy, 11(1), 25-55.

Gaus, G. F. (2005). The moral foundations of liberal neutrality. In T. Christiano \& J. Christman (Eds.), Contemporary debates in poltical philosophy (pp. 81-98). Hoboken, NJ: Wiley.

Hsieh, N. (2000). Moral desert, fairness and legitimate expectations in the market. Journal of Political Philosophy, 8(1), 91-114.

Hurka, T. (2003). Desert: Individualistic and holistic. In S. Olsaretti (Ed.), Desert and justice (pp. 45-68). Cambridge: Cambridge University Press.

Kagan, S. (2012). The geometry of desert. New York: Oxford University Press.

Kleinig, J. (1971). The concept of desert. American Philosophical Quarterly, 8(1), 71-78.

Konow, J. (2001). Fair and square: The four sides of distributive justice. Journal of Economic Behavior \& Organization, 46(2), 137-164.

Krugman, P. (1994). The age of diminished expectations (3rd ed.). Cambridge: MIT Press.

Kuhn, T. S. (1977). The essential tension. Chicago: University of Chicago Press.

Lippert-Rasmussen, K. (2001). Egalitarianism, option luck, and responsibility. Ethics, 111(3), 548-579.

Lippert-Rasmussen, K. (2016). Luck egalitarianism. London: Bloomsbury.

McLeod, O. (2013). Desert. In E. N. Zalta (Ed.), Stanford encyclopedia of philosophy, Winter 2013 edition. http://plato.stanford.edu/archives/win2013/entries/desert/. Accessed 22 May 2018.

Miller, D. (2001). Principles of social justice. Cambridge: Harvard University Press.

Miller, D. (2003). Comparative and noncomparative desert. In S. Olsaretti (Ed.), Desert and justice (pp. 25-44). Cambridge: Cambridge University Press.

Moriarty, J. (2013). Smilansky, Arneson, and the asymmetry of desert. Philosophical Studies, 162(3), $537-545$.

Moriarty, J. (2018). Desert-based justice. In S. Olsaretti (Ed.), The oxford handbook of distributive justice (pp. 152-175). Oxford: Oxford University Press.

Mulligan, T. (2018). Justice and the meritocratic state. New York: Routledge.

Nozick, R. (1974). Anarchy, state, and utopia. New York: Basic Books.

Olsaretti, S. (2003). Desert and justice. Oxford: Clarendon Press.

Olsaretti, S. (2004). Liberty, desert and the market: A philosophical study. Cambridge: Cambridge University Press.

Olsaretti, S. (2006). Desert, justice and luck. In J. Dryzek, B. Honig, \& A. Philips (Eds.), The oxford handbook of political theory (pp. 436-449). Oxford: Oxford University Press.

Olsaretti, S. (2009). Responsibility and the consequences of choice. Proceedings of the Aristotelian Society, 109(2), 165-188.

Pojman, L. P., \& McLeod, O. (1999). What do we deserve? A reader on justice and desert. New York: Oxford University Press.

Quong, J. (2011). Liberalism without perfection. Oxford: Oxford University Press.

Rakowski, E. (1991). Equal justice. New York: Oxford University Press.

Rawls, J. (1971). A theory of justice. Cambridge, MA: Belknap Press.

Roemer, J. E. (1998). Theories of distributive justice. Cambridge: Harvard University Press.

Sadurski, W. (1987). Giving desert its due: Social justice and legal theory. Dordrecht: D. Reidel.

Scheffler, S. (1992). Responsibility, reactive attitudes, and liberalism and philosophy and politics. Philosophy \& Public Affairs, 21(4), 299-323.

Scheffler, S. (2003). What is egalitarianism? Philosophy \& Public Affairs, 31(1), 5-39. 
Schmidtz, D. (2002). How to deserve. Political Theory, 30(6), 774-799.

Schmidtz, D. (2006). Elements of justice. New York: Cambridge University Press.

Segall, S. (2010). Health, luck, and justice. Princeton: Princeton University Press.

Segall, S. (2015). What's so egalitarian about luck egalitarianism? Ratio, 28(3), 349-368.

Sheffrin, S. (2013). Tax fairness and folk justice. New York: Cambridge University Press.

Sher, G. (1987). Desert. Princeton: Princeton University Press.

Sie, M. M. S. K., \& Pereboom, D. (2016). Basic desert, reactive attitudes, and free will. New York: Routledge.

Smilansky, S. (1996a). The connection between responsibility and desert: the crucial distinction. Mind, 105(419), 485-486.

Smilansky, S. (1996b). Responsibility and desert: Defending the connection. Mind, 105(417), 157-163.

Stemplowska, Z. (2009). Making justice sensitive to responsibility. Political Studies, 57(2), 237-259.

Tan, K.-C. (2008). A defense of luck egalitarianism. Journal of Philosophy, 105(11), 665-690.

Temkin, L. S. (1993). Inequality. New York: Oxford University Press.

Temkin, L. S. (2003). Equality, priority or what? Economics and Philosophy, 19(1), 61-87.

Temkin, L. S. (2011). Justice, equality, fairness, desert, rights, free will, responsibility, and luck. In C. Knight \& Z. Stemplowska (Eds.), Responsibility and distributive justice (pp. 51-77). Oxford: Oxford University Press.

Temkin, L. S. (2017). Equality as comparative fairness. Journal of Applied Philosophy, 34(1), 43-60.

Vallentyne, P. (2002). Brute luck, option luck, and equality of initial opportunities. Ethics, 112(3), $529-557$.

Voigt, K. (2007). The harshness objection: Is luck egalitarianism too harsh on the victims of option luck? Ethical Theory and Moral Practice, 10(4), 389-407.

Walzer, M. (1983). Spheres of justice: A defense of pluralism and equality. New York: Basic Books.

Zimmerman, M. J. (1993). Luck and moral responsibility. In D. Statman (Ed.), Moral luck (pp. 217-234). Albany, NY: SUNY Press. 